\title{
Wat ons gezegd wordt over kernenergie
}

\author{
Een analyse van de ideologische strategieën in het discours van \\ de Belgische nucleaire lobby en regering
}

Michelle Van Impe

Kernenergie is omstreden in België en hoewel de overheid zich geëngageerd heeft tot een nucleaire exit in 2025, zijn er weinig beleidsinitiatieven die het land op een dergelijke toekomst voorbereiden. De beeldvorming speelt een belangrijke rol in het debat over nucleaire energie. In deze bijdrage analyseert de auteur het discours over kernenergie van de nucleaire lobby en regering vanuit een groen criminologisch perspectief. Ze vergelijkt het discours met wetenschappelijke literatuur over kernenergie en identificeert ideologische strategieën vanuit het kader van Larrain (1983).

\section{Inleiding}

Sinds 1985 telt België zeven operationele kernreactoren. Na de kernramp in Tsjernobyl (1986) installeerde de Belgische overheid echter een moratorium op de bouw van nieuwe reactoren. In 2003 stemde de paars-groene coalitie (1999-2003) voor een wet die de levensduur van de kerncentrales op maximaal 40 jaar vastlegt en een volledige nucleaire exit in 2025 onderschrijft. ${ }^{1}$ Overeenkomstig deze wet dienden de drie oudste kerncentrales in 2015 gesloten te worden. De regering Di Rupo (2011-2014) verlengde echter de levensduur van kerncentrale Tihange 1 met tien jaar, terwijl de huidige regering Michel (2014-2018) besliste om de reactoren van Doel 1 en 2 tot 2025 open te houden. Momenteel vertegenwoordigen de zeven kerncentrales op de locaties van Doel en Tihange 50 procent van de elektriciteitsbevoorrading, waardoor kernenergie de belangrijkste binnenlandse energiebron vormt (FOD Economie, 2016). Het bedrijf Engie Electrabel - de uitbater van de kerncentrales - bekleedt een monopoliepositie op de energiemarkt, waardoor België de facto afhankelijk is van nucleaire energie en haar enige producent. De rampen in Tsjernobyl (1986) en Fukushima (2011) hebben bijgedragen tot een negatief beeld van de veiligheid van kernenergie. Daarnaast is de bevolking bezorgd over de berging en het gevaar van kernafval (Poumadère e.a., 2011; Ramana, 2017). Daartegenover wordt kernenergie ook als een belangrijke energievorm in de strijd tegen de klimaatopwarming voorgesteld (Kopytko \& Perkins, 2011). Er bestaat echter discussie over de voor- en nadelen van kernenergie (Abbott, 2011). Enkele Belgische centrales hebben reeds meermaals tijdelijk stilgelegen omwille van veiligheidsrisico's en herstelwerken en in Doel 4 was er in 2014 sprake van opzettelijke sabotage, met een olielek tot gevolg. Verder werd er

1 Wet van 31 januari 2003 houdende de geleidelijke uitstap uit kernenergie voor industriële elektriciteitsproductie, BS 28 februari 2003. 
zowel in Nederland als in Duitsland geprotesteerd tegen de verdere exploitatie van Doel 3 en Tihange 2, nadat er waterstofvlokken in de reactorwanden aangetroffen werden. Tot slot lag op de terreinen van Doel en Tihange in 2014 zo'n 3.260 ton uranium opgeslagen en zijn de (toekomstige) kosten voor het beheer van kernafval hoog. ${ }^{2}$

Hoewel de nucleaire exit in 2025 zowel wettelijk als in het huidige regeerakkoord verankerd is (Federale Regering Michel, 2014), zijn er weinig concrete beleidsinitiatieven die België op een bestaan zonder kernenergie voorbereiden. Bij aanvang van de legislatuur (2014) stelde de regering dat ze een energievisie zonder nucleaire energie zou ontwikkelen voor 2030-2050. Pas in december 2017 werden de onderhandelingen afgerond en kwam er een voorstel tot een energiepact waarin de kernuitstap in 2025 werd bevestigd. Het energiepact dient evenwel nog goedgekeurd te worden door het parlement, terwijl de regeringspartij N-VA reeds weigert om dit te doen. Er wordt verwacht dat de kernuitstap een verkiezingsthema zal vormen in 2019, terwijl de 'deadline' in 2025 enkel kan worden gehaald indien onmiddellijk ingezet wordt op een energieomslag. Daarnaast wordt de onafhankelijkheid van de overheid in dit dossier betwijfeld door de politieke oppositie, milieuorganisaties en journalisten. Zo zijn de precieze omstandigheden van de recente levensduurverlengingen weinig bekend: documenten werden achtergehouden door de regering, de nucleaire rente daalt en de overheid is Electrabel een schadevergoeding verschuldigd wanneer de centrales toch voor $2025 \mathrm{zou}$ den sluiten (Soenens, 2017). De Belgische kernuitstap in 2025 is vooralsnog een onzekerheid.

\section{Ideologie, discours en ecologische justitie}

Groene criminologie bestudeert praktijken die direct en indirect ecologische schade teweegbrengen (Ruggiero \& South, 2013). Traditioneel criminologisch onderzoek focust eerder op gedragingen die leiden tot menselijk slachtofferschap en in mindere mate op situaties waarbij dieren of het milieu schade ondervinden. Vanuit de groene criminologie wordt het schadebegrip doorgaans breder ingevuld (Lynch \& Stretesky, 2013). 'Ecologische rechtvaardigheid' staat voor de bescherming van gehele ecosystemen, dieren en mensen en stelt dat elk organisme een intrinsieke waarde heeft, losstaande van de instrumentele functie die mensen eraan toebedelen. Mensen zijn slechts onderdeel van complexe ecosystemen die beschermd zouden moeten worden (White, 2008). Deze omvattende invulling van het schadebegrip is het uitgangspunt in deze bijdrage. Aangezien machtige actoren - zoals de overheid en de industrie - de omschrijving van milieudelicten mee kunnen bepalen, noopt groen criminologisch onderzoek vaak tot een bredere visie dan wettelijk omschreven schadelijk gedrag (Opsal \& O'Connor Shelley, 2014). Naast het regulerende domein construeren bedrijven en belangengroepen het milieu(on)vriendelijke imago van hun activiteiten (bijvoorbeeld door middel van greenwashing). Een prominente strategie is het uitdragen van vertekende infor- 
matie en lobbyorganisaties stellen zich dan ook vaak voor als expertisecentra die objectieve kennis verspreiden (White, 2008; Soenens, 2017). Door te focussen op andere zaken mystificeren machtige actoren hun capaciteit tot het stellen van schadelijk gedrag (Box, 1983). Lobbygroepen en politieke partijen hanteren een ideologisch discours.

Ideologie is een constructieproces van overtuigingen en ideeën dat zich vertaalt in discours en sociale praktijken. Ideologie is functioneel voor (machtige) groepen die hun positie willen behouden of versterken en tracht kennis omtrent fenomenen te verbergen, te vervormen of te verklaren, zodat onderliggende problemen - zoals sociale ongelijkheid of milieuschade - op de achtergrond komen te staan (Larrain, 1983). Discours geeft (ideologische) betekenis aan kennis en kan aangewend worden als middel om het individueel of collectief bewustzijn te beïnvloeden en ongelijke machtsverhoudingen te bestendigen (Blommaert \& Verfaillie, 2016). De (selectieve) wijze waarop informatie over gebeurtenissen verspreid wordt, draagt bij tot een constitutief proces waarin realiteiten gecreëerd worden (Brisman \& South, 2012). Discours, ideologie en macht zijn bijgevolg met elkaar verweven (Blommaert \& Verfaillie, 2016). Verder bouwend op de filosofie van Marx, definieert Larrain (1983) vier strategieën om ideologische elementen via vertogen te maskeren: (1) ontkennen (i.e. een fenomeen bestaat niet), (2) misverstaan (i.e. een fenomeen wordt niet begrepen, waardoor er geen gevolg aan wordt gegeven), (3) de aandacht vestigen op andere fenomenen en (4) het minimaliseren van fenomenen. Ideologische discoursen kunnen echter in vraag gesteld en gedeconstrueerd worden (Chomsky, 2002).

\section{Doelstelling}

Kernenergie is een complex thema. In de discussie omtrent de Belgische nucleaire exit worden de voor- en nadelen tegen elkaar afgewogen door voor- en tegenstanders. Voor de publieke opinie zijn de veiligheidsrisico's en het kernafval belangrijke zorgen, terwijl de potentiële rol van kernenergie in de strijd tegen klimaatverandering eveneens overwogen wordt (Poumadère e.a., 2011). Deze zaken zijn prominent aanwezig in het debat en diverse - soms tegenstrijdige - informatie wordt door allerhande stakeholders verspreid. Het doel van deze bijdrage is het discours van de nucleaire lobby en de huidige Belgische regering te analyseren, vanuit het idee van 'ecologische rechtvaardigheid' en Larrain's (1983) kader. De veiligheid en milieuvriendelijkheid van kernenergie worden vanuit wetenschappelijke literatuur nagegaan, waarna Larrain's (1983) kader zich leent voor een diepgaande discoursanalyse en een deconstructie van aanwezige ideologische elementen.

De keuze om te focussen op de pro-nucleaire lobby berust op drie argumenten: (1) door de Belgische afhankelijkheid van kernenergie heeft de nucleaire industrie een machtige positie; (2) deze gunstige situatie staat onder druk door de kernuitstap; en (3) de kernenergielobby tracht haar positie (zo lang mogelijk) te behouden. Vanuit de kritische en groene criminologie is het bijzonder interessant om het gedrag van machtige actoren te bestuderen wanneer hun positie in het 
gedrang komt. De keuze om daarnaast het discours van de regering te analyseren, komt voort uit het idee dat deze een beleid voert dat bepalend is voor de haalbaarheid van de kernuitstap in 2025. Dit neemt niet weg dat tegenstanders van kernenergie ook een ideologisch discours hanteren, dat evenzeer belangrijk is om te bestuderen. Binnen het bestek van deze bijdrage was hier echter onvoldoende ruimte voor.

\section{Methodologie}

Het literatuuronderzoek spitste zich toe op wetenschappelijke bronnen. Documenten van contra-nucleaire organisaties werden bewust niet opgenomen, om te waken over de objectiviteit. Verder focusten we op literatuur die de veiligheid, de rol in de klimaatverandering, het kernafval en de toekomst van kernenergie behandelt, omdat dit de voornaamste zorgen van de bevolking zijn. Vervolgens identificeerden we drie organisaties als Belgische nucleaire belangengroepen. Deze instellingen zijn rechtstreeks afhankelijk van het bestaan van kernenergie, hebben alle een nationale werkingssfeer en nemen de functie op zich de bevolking te informeren over kernenergie:

- Nucleair Forum

Het Nucleair Forum is een pro-nucleaire lobbygroep, maar profileert zich als de referentie bij uitstek voor kerntechnologie ten aanzien van de pers, beleidsverantwoordelijken en de bevolking. Daarnaast streven ze naar kennisbevordering op basis van objectieve wetenschappelijke feiten. Deze vereniging organiseert campagnes in de vorm van documenten, reclames, filmpjes en informatiereizen voor politici en de pers. Het Nucleair Forum verenigt nucleaire belanghebbenden en zodoende ook de overige lobbygroepen die we in dit artikel bestuderen. Verder is het Studiecentrum voor Kernenergie (SCK) - een federale onderzoeksinstelling die onder meer de veiligheid van de nucleaire industrie controleert - eveneens aangesloten bij deze lobbygroep. De controlerende instantie is bijgevolg lid samen met de bedrijven die zij moet controleren.

- Engie Electrabel

Het nationaal productiemonopolie van Electrabel maakt dit bedrijf tot een rechtstreeks belanghebbende partij. De Belgische overheid en Electrabel hebben een historische afhankelijkheidsrelatie: de overheid reguleert de energiemarkt en gaf Electrabel haar huidige positie. Daarnaast voorzien de kerncentrales België van goedkope energie en vloeit een deel van de winst terug naar de staat via de nucleaire rente. Ook Electrabel is lid van het Nucleair Forum.

- Belgian Nuclear Society (BNS)

De BNS heeft tot doel bedrijven, onderzoekers en studenten te verenigen en objectieve informatie te verspreiden over kernenergie. Deze organisatie is de Belgische poot van de Europese lobby en zowel Electrabel als het Belgisch Studiecentrum voor Kernenergie (SCK) is erbij aangesloten. Daarnaast wordt de BNS gesponsord door Bel V (dit is het controleorgaan van het Federaal Agent- 
schap voor Nucleaire Controle), het Nucleair Forum en Tractebel Engie (een zusteronderneming van Electrabel).

- Federale regering

De huidige federale regering (Michel, 2014-2018) bestaat uit drie Vlaamse en één Waalse politieke partij, namelijk de Nieuw-Vlaamse Alliantie (N-VA), de Open Vlaamse Liberalen en Democraten (Open Vld), de Vlaamse Christendemocraten $(C D \& V)$ en de Mouvement Réformateur (MR).

\section{Dataverzameling en -analyse}

De dataverzameling beperkte zich tot publiek toegankelijke communicatie die erop gericht is de bevolking te informeren. Hiervoor doorzochten we websites, partijprogramma's, informatiedocumenten, campagnes, televisie- en kranteninterviews en hanteerden we een afbakenperiode die loopt van 2015 tot 2017, om zo recente ontwikkelingen te belichten. Een uitzondering hierop is een document van de BNS uit 2012; dit wordt op hun website als de voornaamste informatiebron voor het publiek gepresenteerd. Daarnaast focusten we op data omtrent de veiligheid, de rol van nucleaire energie bij klimaatverandering en verklaringen over de kernuitstap. Veelal werden op de websites van de lobbygroepen specifieke rubrieken aan deze thema's gewijd. Het discours van de regering troffen we eerder aan in de pers, gezien de meeste regeringspartijen (behoudens N-VA) nog geen verkiezingsstandpunten gelanceerd hebben. Bij de data-analyse werd relevante informatie samengebracht onder de eerdergenoemde overkoepelende thema's en vervolgens gestructureerd naar specifieke topics. Verder hielden we de data tegen het licht van het wetenschappelijk literatuuronderzoek en Larrain's (1983) vier strategieën. Door verschillende databronnen samen te brengen en te analyseren volgens deze vier principes identificeerden we een selectief en ideologisch discours.

\section{De milieu(on)vriendelijkheid en veiligheid van kernenergie}

\section{Nood aan natuurlijke grondstoffen}

De nucleaire industrie heeft nood aan verschillende grondstoffen, zoals uranium, andere metalen en water (Scheire \& Van den Abeele, 2009). De globale uraniumreserves zullen binnen 80 jaar uitgeput zijn (Dittmar, 2012). Uranium is veelvuldig aanwezig in zeewater, maar er is vooralsnog geen kostenefficiënte wijze ontwikkeld voor ontginning. Bovendien wordt verwacht dat de ecologische schade - door het chemisch onttrekken van een essentieel bestanddeel - aanzienlijk zal zijn. Daarnaast worden ook de reactorvaten uit zeldzame materialen geproduceerd, die eveneens ontgonnen moeten worden (Abbott, 2011; Sovacool, 2008). Mijnontginning is een vervuilende en destructieve industrie voor de ecologische omgeving en de sociale gemeenschappen die er gevestigd zijn (Jenkins, 2004). Daarnaast zijn de werkomstandigheden in de mijnen vaak schrijnend, is er sprake van geweld, land grabbing, mensenrechtenschendingen en zijn het vooral de westerse bedrijven die grote winsten boeken (Graetz, 2014). 
Belangrijke uraniumbevoorradingsregio's - zoals Mali, Niger en Congo - worden bovendien gekenmerkt door politieke instabiliteit, waardoor de bevoorrading niet verzekerd is (Scheire \& Van den Abeele, 2009). In stabiele uraniumlanden, zoals Australië, Canada en de Verenigde Staten, stelt het probleem zich dat 70 procent van de uraniumertsen zich op gronden van 'first peoples', zoals Aboriginals en indianenstammen, bevindt. Omwille van stralingsblootstelling en de vervuiling van bodem en water heeft uraniumontginning een negatieve gezondheidsimpact op de bewoners en de mijnwerkers (Graetz, 2014). Daarnaast hebben nucleaire centrales grote hoeveelheden water nodig om de reactorkernen te koelen. Martín en del Mar Rubio-Varas (2017) berekenden dat de Spaanse kerncentrales zo'n $70 \mathrm{~m}^{3}$ zoet water per capita/jaar nodig hebben om veilig te functioneren. Bovendien ondermijnen hittegolven en droogte de beschikbaarheid van koelwater (Poumadère e.a., 2011; Ramana \& Ahmad, 2016).

\section{Klimaatverandering}

Kernenergie wordt omschreven als een mogelijke oplossing voor de klimaatopwarming omdat ze $\mathrm{CO}_{2}$-arm en goedkoop is. Hierover bestaat echter discussie (Abbott, 2011; Kopytko \& Perkins, 2011). De productie van kernenergie stoot op zichzelf geen $\mathrm{CO}_{2}$ uit, maar het totale proces wél. Verschillende studies hebben getracht de $\mathrm{CO}_{2}$-uitstoot van de nucleaire cyclus te berekenen. Het betreft de ontginning, verrijking en verwerking van uranium en andere grondstoffen, de opbouw van de nucleaire site, afvalverwerking, -transport en -opslag, alsook de ontmanteling van de centrales en ruiming van de (mijn)sites (Sovacool, 2008). Afhankelijk van de aspecten die mee in beschouwing genomen worden, het type reactor en de aangewende methodologie, variëren de berekeningen aanzienlijk. Cijfers geven een uitstoot aan tussen $8 \mathrm{~g}$ en meer dan $130 \mathrm{~g} \mathrm{CO} / \mathrm{kWh}$ (Beerten e.a., 2009; Lenzen, 2008). Op basis van verschillende studies berekende Sovacool (2008) dat de gemiddelde uitstoot van een nucleaire centrale $66 \mathrm{~g} \mathrm{CO}_{2} / \mathrm{kWh}$ bedraagt. Hoewel de uitstoot aanzienlijk lager ligt dan bij fossiele brandstoffen, is het gemiddelde cijfer hoger dan bij windenergie en hydro-elektriciteit (tussen 15 en $34 \mathrm{~g} \mathrm{CO}_{2} / \mathrm{kWh}$ ) en in sommige gevallen hoger dan bij zonne-energie (ongeveer 50-90 g CO $2 / \mathrm{kWh}$ ) (Lenzen, 2008; Nugent \& Sovacool, 2014). Niettegenstaande bestaat er over de $\mathrm{CO}_{2}$-uitstoot van hernieuwbare energievormen eveneens onenigheid. De $\mathrm{CO}_{2}$-uitstoot van kernenergie is bijgevolg geen wetenschappelijk uitgemaakte zaak.

Daarnaast kan klimaatverandering juist een obstakel voor kernenergie vormen. Overstromingen van nucleaire sites, geologische instabiliteit, hittegolven en droogte worden immers verwacht frequenter én intenser voor te komen (Kopytko \& Perkins, 2011; Martín \& del Mar Rubio-Varas, 2017). Deze omstandigheden zullen een negatieve impact hebben op het functioneren van de centrales en zullen de kans op een nucleaire ramp vergroten (Abbott, 2011; Lhotka e.a., 2017). Zo leidden de Europese hittegolven in 2003 - met een lagere rivierstand en warmer water tot gevolg - ertoe dat de Franse centrales niet optimaal en veilig konden functioneren. Het land produceerde minder energie en zette de export naar Italië tijdelijk stop, waardoor aldaar verschillende regio's zonder stroom vielen (Kopytko \& Perkins, 2011). Tijdens hittegolven stijgt bovendien de vraag naar 
energie en water, waardoor de afhankelijkheid van kernenergie problematischer wordt (Lhotka e.a., 2017).

Nucleaire rampen, terroristische aanslagen en wapenproliferatie

Ongelukken kunnen getriggerd worden door onvoorziene omstandigheden en zowel kwestbare centrales als verzwakte veiligheidssystemen kunnen daarvan de oorzaak zijn (Abbott, 2011). De aanleiding tot de Fukushima-ramp (2011) was een aardverschuiving en een tsunami, maar de kernsmelting werd veroorzaakt doordat cruciale veiligheidssystemen faalden (Levi \& Horlick-Jones, 2013). De kans op een kernramp is bijzonder klein en de nucleaire sector wordt onderworpen aan strenge controles, maar indien een ramp toch voorvalt, zijn de gevolgen catastrofaal voor de bevolking en het ecosysteem (Abbot, 2011). Chronische stralingsblootstelling heeft rond de sites van Tsjernobyl en Fukushima nog steeds een negatief effect op mens, fauna en flora (Mousseau \& Møller, 2014; Nesterenko e.a., 2009). De impact van een kernramp is een verborgen financiële kostenpost, die kan oplopen tot honderden miljarden euro's (Abbot, 2011).

Een bijkomend risico bestaat eruit dat radioactieve materialen aangewend kunnen worden voor de ontwikkeling van wapens (Vander Beken e.a., 2010). Met enkele kilo's splijtstof kan men een nucleaire bom maken (Socolow \& Glaser, 2009). Tijdens beide Golfoorlogen gebruikten de Verenigde Staten verarmd uranium als munitie en bracht het vrijgekomen radioactieve stof schade toe aan burgers, soldaten en het milieu (White, 2008). Daarnaast kunnen de centrales, de opslagplaatsen en het transport van radioactief afval het doelwit worden van terroristen (Vander Beken e.a., 2010).

\section{Kernafual}

Ongeveer 75 procent van het radioactief afval in België is laagactief en 1 procent is hoogactief. Deze ene procent bevat echter 95 procent van de totale radioactiviteit (NIRAS, 2017). Daarnaast stoot elke vorm van nucleaire energie neutronen uit die in de reactorvaten scheurtjes veroorzaken en ze radioactief maken. Hierdoor dient elke centrale na 40-60 jaar ontmanteld te worden (Abbott, 2011). Kernafval blijft - afhankelijk van de halfwaardetijd - 100 tot 10.000 jaar gevaarlijk. Er wordt reeds 40 jaar lang onderzoek gedaan naar de finale opslagmogelijkheden van kernafval. Inmiddels stellen experts de berging in geologische lagen - zoals klei of graniet - voor, omdat deze formaties miljoenen jaren stabiel geweest zijn. Bij gebrek aan operationele geologische bergplaatsen is hier echter geen empirisch bewijs van (Ramana, 2017; Dittmar, 2012). Bovendien zal geen enkele opslagplaats nucleair afval voor een onbepaalde duur kunnen beveiligen, vallen de repercussies en investeringen moeilijk te voorspellen en zadelen we toekomstige generaties op met de last om het afval te beveiligen (Ramana, 2017). 


\section{Resultaten discoursanalyse}

\section{Ontkennen}

Het expliciet ontkennen van gebeurtenissen komt in één geval duidelijk naar voren, namelijk in de communicatie omtrent de 'scheurtjes/waterstofvlokken' in de reactorvaten van Tihange 2 en Doel 3. De regering, de controlerende overheidsinstellingen, de uitbater en de nucleaire lobby verzekeren de veiligheid van de centrales en wijzen erop dat de waterstofvlokken niet te wijten zijn aan slijtage: 'Na verder onderzoek, bleek het om waterstofinsluitsels te gaan, een gekend fenomeen in de metallurgie. Deze insluitsels werden in de media onterecht "scheurtjes" genoemd' (Electrabel, z.d., 13). Verschillende (inter)nationale materiaaldeskundigen en experts in nucleaire veiligheid zijn echter van mening dat het wel degelijk om scheurtjes gaat (Soenens, 2017). Zowel minister Marghem van Energie, Leefmilieu en Duurzame Ontwikkeling (MR) als minister Jambon van Binnenlandse Zaken (N-VA) reageert op de berichten dat 'onze kerncentrales veilig zijn' en 'geen enkel nucleair gevaar vormen' (Marghem, 2016; Jambon, 2016). Welke experts gelijk hebben, blijft een raadsel. De tegenstrijdigheid en het taalgebruik - i.e. 'waterstofvlokken' tegenover 'scheurtjes' - zijn alleszins frappant.

Ontkenning kunnen we ook impliciet afleiden uit het feit dat men cruciale informatie niet vermeldt. Zo beschrijft Electrabel de voordelen van kernenergie als volgt: 'Geen uitputting van fossiele brandstoffen; een van de goedkoopste bronnen om elektriciteit te produceren in België, elektriciteit in grote volumes en zonder $\mathrm{CO}_{2}$-uitstoot' (Electrabel, 2017). De uitputting van uranium, de aanzienlijke (toekomstige) kosten én de $\mathrm{CO}_{2}$-uitstoot worden niet vermeld. De BNS verklaart dat:

'voor onze energiebevoorrading kernenergie als een veilige, betrouwbare energiebron kan worden beschouwd. De uraniumreserves zijn verspreid over verschillende, overwegend stabiele regio's (...) Vanuit strategisch oogpunt vormt kernenergie voor Europa (...) een belangrijke factor van stabiliteit en energieonafhankelijkheid.' (BNS, 2012, 41)

Deze voorstelling van kernenergie is bevreemdend, aangezien we afhankelijk zijn van (eindige) buitenlandse grondstoffen uit ofwel onstabiele regio's met nietdemocratische regimes, ofwel stabiele regio's waar de rechten van first peoples in het gedrang komen (Scheire \& Van den Abeele, 2009; Graetz, 2014).

\section{Misverstaan}

Het misverstaan van een fenomeen is erop gericht een impasse te creëren, opdat actie overbodig wordt. Hoewel er overlap is met de impliciete ontkenning, beargumenteren we dat via deze strategie 'feiten' uitgedragen worden waarover (nog) geen consensus bestaat. Zowel de lobby als actoren binnen de regering 'misverstaan' de wetenschappelijke realiteit van bepaalde aspecten van kernenergie, zoals de $\mathrm{CO}_{2}$-uitstoot en de berging van kernafval. $\mathrm{De} \mathrm{CO}_{2}$-uitstoot is rechtstreeks gerelateerd aan het al dan niet milieuvriendelijke karakter van nucleaire energie. Uit het literatuuronderzoek kwam naar voren dat er hieromtrent geen wetenschappe- 
lijke duidelijkheid bestaat en dat de cijfers sterk variëren. De lobby tracht kernenergie echter van een groene(re) signatuur te voorzien en gaat daarmee voorbij aan de complexiteit van de kwestie. Zo stelt het Nucleair Forum:

'Wanneer we de hele levenscyclus van een kerncentrale bekijken, ligt de $\mathrm{CO}_{2}$ uitstoot van kerncentrales merkelijk lager dan die van fossiele brandstoffen. $\mathrm{Ze}$ is vergelijkbaar met die van hernieuwbare energiebronnen.' (Nucleair Forum, 2017b)

Het Nucleair Forum preciseert dat kerncentrales en windmolenparken 12 g CO$_{2} /$ $\mathrm{kWh}$ uitstoten, terwijl zonnepanelen goed zijn voor $27 \mathrm{~g} \mathrm{CO}_{2} / \mathrm{kWh}$. De bronverwijzing voor deze informatie is vaag en ook na een grondige zoektocht konden het rapport noch de cijfers getraceerd worden. Electrabel schaart zich eveneens achter dit idee: 'In België besparen we dankzij kernenergie evenveel $\mathrm{CO}_{2}$ als de uitstoot van het hele wagenpark!' (Electrabel, z.d., 33). In 2015 klinkt ook bij minister Marghem (MR): 'Le nucléaire émet moins de $\mathrm{CO}_{2}$ que le photovoltaïque et autant que les éoliennes' (Le Soir, 2015).

De finale berging van kernafval wordt eveneens misverstaan. De veilige en langdurige opslag van hoogradioactief afval is nog niet empirisch getest en het is twijfelachtig of er een manier bestaat om het afval veilig te bewaren tot het zijn radioactiviteit verliest (Ramana, 2017; Dittmar, 2012). De nucleaire lobbyorganisaties verzekeren echter dat de Boomse klei 'zeer geschikt [is] voor de risicoloze berging gedurende honderdduizenden jaren' (Nucleair Forum, 2017c). De BNS gaat er prat op dat 'opslaginfrastructuren in diepe en stabiele geologische lagen hun isolerend vermogen gedurende miljoenen jaren hebben bewezen of in staat zijn om de eventuele migratie van radionucliden naar de biosfeer zeer doeltreffend te beperken' (BNS, 2012, 85). We betwijfelen niet dat de geologische berging een geschikt scenario lijkt, maar dit idee voorstellen als onfeilbaar is incorrect. De eerste kernreactor werd opgestart in 1969, waardoor kernenergie en hoogradioactief afval iets ouder zijn dan een halve eeuw. De indruk dat bepaalde geologische lagen hun beveiligende capaciteit voor dergelijk hoogradioactief materiaal reeds miljoenen jaren bewezen hebben, is een misleidende omschrijving.

\section{De aandacht vestigen op andere zaken}

We identificeerden deze strategie voornamelijk in het discours van de regering, die het debat over kernenergie vernauwt tot de "bevoorradingszekerheid van betaalbare energie'. In de winter van 2014-2015 werd België overmand door een crisissfeer, toen de media berichtten dat een black-out nabij was. Doel 1 en 2 werden onmisbaar geacht en de regering verlengde de levensduur van beide centrales. De $\mathrm{CREG}^{3}$ publiceerde in juni 2015 een rapport dat de berekening van de nakende black-out tenietdeed en aangaf dat België ook zonder deze centrales nog ver verwijderd was van het gebruik van de reserves (CREG, 2015). Opvallend is dat verschillende regeringspartijen het idee van een black-out zonder deze centrales blijven aanwenden als knelpunt. Zo stelt minister Marghem (MR): 'Zonder die pro- 
ductie zou ons land zich vandaag in een veel complexere situatie bevinden. Dit is het bewijs dat de verlenging van die twee centrales onontbeerlijk was' (De Morgen, 2016).

N-VA (2017) geeft aan dat '[s]troomonderbrekingen nefast zijn voor onze gezinnen en onze industrie (...) Wij willen een realistisch scenario voor de kernuitstap, tegen uiterlijk 2065.' Naar aanleiding van de recent overeengekomen energievisie waarin de kernuitstap tegen 2025 behouden blijft, heeft N-VA verklaard geen energiepact goed te keuren, mits er afgestapt wordt van deze deadline. De facto betekent dit dat concrete beslissingen binnen het energiedossier onmogelijk gemaakt worden. Een CD\&V-kamerlid geeft aan dat '[a]ls de N-VA niet wil dat we beslissen, beslissen we eigenlijk ook: dan blijft het kernenergie' (Mabrouk, 2017). In 2017 verklaarde minister Tommelein dat '[w]e de kerncentrales nog een tijdje nodig hebben voor de bevoorrading, want we hebben nog altijd te weinig hernieuwbare energie' (De Morgen, 2017). Naar aanleiding van de recente patstelling door N-VA lijkt minister Tommelein echter aan te dringen op de kernuitstap en zegt hij 'stomverbaasd' te zijn dat N-VA zich in deze kwestie laat leiden door 'grote lobbygroepen' (Belga, 2017). Het standpunt van CD\&V over de toekomst van kernenergie is eveneens verschillende malen gewijzigd. Anno 2017 lijkt de partij de nucleaire exit te onderschrijven, maar vreest ze ervoor de transitie in 2025 niet te halen. Ook voor CD\&V is het essentieel dat het licht blijft branden, waardoor ze de deur op een kier zet voor de verdere exploitatie van nucleaire energie (Van Horenbeek \& De Boeck, 2017).

De nucleaire lobby maakt eveneens gebruik van deze strategie en verschuift de aandacht voornamelijk naar de nood aan koolstofarme kernenergie en het idee dat mensen 'verkeerd' geïnformeerd zijn. Betreffende de veiligheid van de centrales verklaart Electrabel:

'In tegenstelling tot wat sommige bronnen soms beweren, zijn onze kerncentrales veilig én voldoen ze aan alle normen (...) Helaas worden bepaalde feiten soms uit hun context gerukt en ontstaan zo, jammer genoeg, foutieve percepties (...) Precies daarom vinden wij het belangrijk om $u$ zo goed mogelijk te informeren en meteen ook mogelijke misverstanden te voorkomen.' (Electrabel, z.d., 2)

De BNS herhaalt de waarschuwing voor misconcepties en maant de overheid aan 'correcte' informatie te ondersteunen:

'In veel gevallen gaapt er werkelijk een kloof tussen de perceptie van risico's door onderzoekers en experten enerzijds en door het grote publiek anderzijds. En het is vaak van die kloof dat specifieke belangengroepen dankbaar gebruik maken.' (BNS, 2012, 6)

Onder de titel 'Beter informeren, dat is beter begrijpen' propageert het Nucleair Forum de noodzaak van kernenergie: 'Om te voldoen aan onze energiebehoefte, met een stabiele bevoorradingszekerheid en een lage CO2-uitstoot [sic], hebben we haar simpelweg nodig' (Nucleair Forum, 2017a). 


\section{Minimaliseren}

We identificeerden de minimaliserende strategie enkel in het discours van de lobby omtrent de veiligheidsrisico's van kernenergie en kernafval. Opvallend is dat de kwestie van het kernafval haast geen onderdeel uitmaakt van het discours van de regering. Open Vld is voorstander om de 'scheurtjescentrales' Doel 3 en Tihange 2 vroeger te sluiten. De partij zet in haar discours in op 'safety first' en kaart de problemen van het nucleair afval en een mogelijke kernramp wel aan (Open Vld, 2016). De andere regeringspartijen mijden deze onderwerpen en houden het bij de bevoorradingszekerheid van goedkope energie. Hoewel dit geen 'minimalisatie' an sich is en de redenen voor de afwezigheid van dit onderwerp niet bekend zijn, is het vanuit de overheid een selectieve wijze om de veiligheid van kernenergie te benaderen.

In 2016 lanceerde het Nucleair Forum een informatiefilmpje over kernenergie als wapen tegen de klimaatverandering (Nucleair Forum, 2016). Ze leidden het fragment in met 'hierbij de feiten', waarna ze aangaven dat kernenergie 'weinig afval produceert, dat streng gecontroleerd wordt', met een bijhorend beeld van een blokje groenkleurig afval naast een paperclip om de gelijke grootte aan te tonen. De risico's van nucleair afval worden dan weer niet toegelicht en de omvang van het kernafval lijkt verwaarloosbaar. Electrabel stelt:

'Radioactief afval vormt slechts een uiterst minieme fractie van het totale afvalvolume dat in België wordt geproduceerd (...) Het hoogradioactief afval komt overeen met 5 gram per persoon per jaar oftewel het equivalent van één vingerhoedje (...) Dit type van afval vertegenwoordigt slechts $1 \%$ van het totale volume radioactief afval in België.' (Electrabel, z.d., 27-28)

De lobbygroepen vermelden echter niet dat die ene procent aan hoogradioactief afval 95 procent van alle radioactiviteit vertegenwoordigt (NIRAS, 2017). Voor deze vorm van afval is een onderverdeling naar volume misleidend en zelfs onzinnig. Zelfs wanneer we mee zouden gaan in het verhaal van de lobby, is de vergelijking met één vingerhoedje per capita/jaar eveneens twijfelachtig: uiteindelijk eindigen we in België jaarlijks met een berg van zo'n 11,35 miljoen vingerhoedjes hoogradioactief afval, wat bezwaarlijk minimalistisch genoemd kan worden.

Naast het volume worden ook de risico's van kernenergie en -afval merkwaardig voorgesteld door de BNS:

'Bestraling is te vergelijken met zonnestralen: om zich daartegen te beschermen, zoekt men de schaduw op of opent men een parasol. Besmetting is vergelijkbaar met regen: om zich daartegen te beschermen, trekt men waterdichte kleren aan.' (BNS, 2012, 15)

Het lijkt alsof er voor elke vorm van straling/besmetting een oplossing bestaat. Op basis van de rampen in Tsjernobyl (1986) en Fukushima (2011) kunnen we deze representatie ontkrachten. De BNS minimaliseert de gevaren nog verder: 'De risico's die verband houden met straling vormen slechts een bijzonder kleine fractie van alle gevaren waaraan burgers in hun omgeving worden blootgesteld' (BNS, 
$2012,19)$ en 'Kernafval is in de eerste plaats een probleem dat sterk op de spits wordt gedreven, vooral ook vanuit emotioneel oogpunt' (BNS, 2012, 89).

\section{Discussie}

Vertrekkend vanuit het idee van 'ecologische rechtvaardigheid', waarbij mensen slechts als onderdeel van complexe ecosystemen worden gezien, kunnen we de (verdere) toepassing van kernenergie beschouwen als een schadelijke praktijk. Zowel mensen, dieren als gehele ecologische systemen ondervinden namelijk negatieve effecten van het totale ontwikkelingsproces van nucleaire energie (Lynch \& Stretesky, 2013; Ruggiero \& South, 2013). De noodzakelijke mijnindustrie is destructief voor de biologische diversiteit en gaat gepaard met mensenrechtenschendingen (Graetz, 2014); de opbouw, operatie en afbraak van nucleaire sites vergen grote hoeveelheden grondstoffen, energie en water (Kopytko \& Perkins, 2011; Ramana \& Ahmad, 2016); en het nucleair afval is een gevaar dat nog duizenden jaren aanwezig zal zijn (Ramana, 2017). Ingeval er sprake is van een nucleaire ramp, terroristische of militaire aanval, zijn de gevolgen non-discriminatoir (White, 2008; Vander Beken e.a., 2010). Transparante, volledige en wetenschappelijke informatie omtrent kernenergie is belangrijk in het debat over het behoud ervan alsmede de schade voor mens, flora en fauna.

In de aanloop naar de Belgische nucleaire exit in 2025 maken verschillende organisaties en politieke partijen hun standpunt over de kwestie bekend. Via het analysekader van Larrain (1983) ondervonden we dat zowel de Belgische nucleaire lobby als de regering selectief informatie weergeeft en schadelijke elementen of knelpunten van kernenergie minimaliseert, misverstaat, niet vermeldt of ontkent. Daarnaast worden wetenschappelijke obstakels en onzekerheden - bijvoorbeeld omtrent nucleair afval en de $\mathrm{CO}_{2}$-uitstoot - op dergelijke wijze beschreven dat de mogelijkheden legio lijken en risico's zeer beperkt worden. Cruciale informatie wordt veelal niet vermeld. Tot slot wordt de aandacht verschoven naar andere zaken, i.e. de bevoorradingszekerheid, de betaalbaarheid en een foutief geïnformeerde bevolking. Het vertoog van zowel de lobby als de regering is ideologisch en mystificeert het kernenergiedossier door er een vervormd beeld van te verspreiden (Box, 1983). Dergelijk discours kan gevolgen hebben voor de sociale realiteit (Blommaert \& Verfaillie, 2016). Recente beleidskwesties - zoals de levensduurverlenging van drie kerncentrales, getalm en veto's omtrent de uitwerking van het energiepact - kunnen beschouwd worden als dergelijke implicaties in die sociale realiteit.

De exploitatie van kernenergie is legaal en wordt gezamenlijk uitgeoefend door private en publieke instellingen die momenteel afhankelijk zijn van nucleaire energie. Bovendien is er rond elk aspect van kernenergie - gaande van de mijnontginning tot de verwerking van nucleair afval - een lucratieve industrie opgebouwd (Vander Beken e.a., 2010; Graetz, 2014). Daarnaast stelt de omschakeling naar een alternatief energiemodel verschillende technische en infrastructurele uitdagingen. Desalniettemin kijken de overheid en de industrie inmiddels vijftien jaar aan tegen deze uitdagingen. De huidige regering - die inderdaad een politiek 
van nucleair immobilisme erft - zal moeten ageren indien ze de kernuitstap in 2025 wil verwezenlijken. Het huidige beleid druist echter in tegen deze filosofie. Hoewel we niet ontkennen dat nucleaire energie voordelen heeft - i.e. het is betaalbaar, 24/7 beschikbaar, en de infrastructuur is reeds voorhanden - wordt het publiek debat ideologisch gestuurd door machtige groepen (Box, 1983). Een onvolledig of incorrect geïnformeerde publieke opinie kan zich immers minder kritische vragen stellen bij een schadelijk beleid (Chomsky, 2002). Tot slot roepen deze zaken vragen op over de onafhankelijkheid van de overheid (Soenens, 2017). Hoewel dit meer diepgaand onderzoek vereist, kunnen we de vraag opwerpen of er in deze case sprake is van state-corporate crime (Kramer e.a., 2002).

Er zijn verschillende beperkingen aan deze studie. Het onderzoek beperkte zich tot het discours van de pro-nucleaire lobby en de regering, terwijl het eveneens wenselijk is om het discours van andere actoren - zoals milieuorganisaties en de politieke oppositie - te bestuderen. Deze case zou gebaat zijn bij een meer diepgaand en contextueel onderzoek. Daarnaast zijn we zelf criminologen en geen nucleaire experts. Het groen criminologisch perspectief waaruit we 'kernenergie' benaderd hebben, gaat onvermijdelijk voorbij aan bijzonder technische en pragmatische zaken die ook een rol spelen in het huidige debat. Politieke besluitvorming vindt immers niet enkel plaats op basis van wetenschappelijke argumenten. De insteek van deze bijdrage is zodoende hoofdzakelijk ethisch van aard en adresseert de schadelijkheid van kernenergie alsook de vertekende informatie die de bevolking hierover verkrijgt. In deze kwestie nemen we als kritische criminologen dan ook een beargumenteerd standpunt in: in het debat over kernenergie wordt de bevolking onthouden van bepaalde kennis - voornamelijk omtrent de negatieve aspecten - door een belanghebbende en machtige nucleaire lobby en de regering. Ook wat de minder aangename zaken betreft vereist deze kwestie van bijzonder publiek belang onzes inziens transparantie, volledigheid en eerlijkheid.

\section{Conclusie}

Binnen de criminologie dienen we aandacht te besteden aan de creatie van kennis over thema's waarin belangen van machtige groepen spelen. Met dit artikel wilden we een bijdrage leveren aan criminologisch onderzoek vanuit het perspectief van ecologische rechtvaardigheid alsook het sociologisch kader omtrent ideologie en macht van Larrain (1983). Kernenergie is een complex onderwerp, waarin belanghebbenden het collectief bewustzijn trachten te beïnvloeden. Een bewustzijn van de ideologie van de bron is belangrijk. Onze nood aan energie en de hiervoor als logisch voorgestelde oplossing van kernenergie lijken aannemelijk en zijn - toegegeven - gemakkelijk. Een meer kritische benadering leidt echter tot een resem aan vragen en vormt het startpunt om potentieel schadelijke keuzes van hogerhand tegen te gaan. Vanuit een breed ecologisch en menselijk welzijnsbegrip is pro-activiteit in deze kwestie essentieel. In dit kernenergiedossier is zowel uitstellen als nietsdoen een keuze die consequenties zal hebben voor de toekomst. 


\section{Literatuur}

Abbott, D. (2011). Is nuclear power globally scalable? Proceedings of the IEEE, 99(10), 1611-1617.

Beerten, J., Laes, E., Meskens, G. \& D'haeseleer, W. (2009). Greenhouse gas emissions in the nuclear life cycle: a balanced appraisal. Energy Policy, 37(12), 5056-5068.

Belga. (2017, 6 december). Kernuitstap blijft voor gekibbel zorgen in Vlaamse meerderheid. Het Laatste Nieuws. Geraadpleegd op www.hln.be/nieuws/binnenland/ kernuitstap-blijft-voor-gekibbel-zorgen-in-vlaamse-meerderheid aa8e6f64/.

Blommaert, J. \& Verfaillie, K. (2016). Discoursanalyse. In: T. Decorte \& D. Zaitch (red.). Kwalitatieve methoden en technieken in de criminologie (derde editie). Leuven/Den Haag: Acco, 321-346.

BNS. (2012). Kernenergie beter begrijpen. Belgian Nuclear Society.

Box, S. (1983). Power, crime, and mystification. London: Tavistock Publications.

Brisman, A. \& South, N. (2012). A green-cultural criminology: an exporatory outline. Crime Media Culture, 9(2), 115-135.

Chomsky, N. (2002). Understanding power (P.R. Mitchell \& J. Schoeffel, eds.). New York: The New Press.

CREG. (2015). Studie over 'de maatregelen die moeten worden genomen teneinde over voldoende conventionele productiemiddelen te beschikken om de bevoorradingszekerheid van elektriciteit van België te waarborgen'. Brussel: Commissie voor de Regulering van de Elektriciteit en het Gas.

De Morgen. (2016, 7 november). Dreigt er stroomtekort in België? Geraadpleegd op www. demorgen.be/binnenland/marghem-ongerust-over-dreigend-stroomtekort-in-belgieb8212d16/.

De Morgen. (2017, 30 juni). Tommelein: 'Ik vind dat de scheurtjescentrales onmiddellijk dicht moeten.' Geraadpleegd op www.demorgen.be/economie/tommelein-ik-vind-datde-scheurtjescentrales-onmiddellijk-dicht-moeten-b7cdc445/.

Dittmar, M. (2012). Nuclear energy: status and future limitations. Energy, 37(1), 35-40.

Electrabel. (2017). Kernenergie:een onmisbare bron van energie. Geraadpleegd op http:// corporate.engie-electrabel.be/nl/lokaal-producent/kernenergie/op 8 augustus 2017.

Electrabel. (z.d.). 50 vragen en antwoorden over kernenergie en onze kerncentrales. Geraadpleegd op http://corporate.engie-electrabel.be/nl/lokaal-producent/kernenergie/50vragen-en-antwoorden-over-kernenergie-en-onze-kerncentrales/.

Federale Regering Michel. (2014). Regeerakkoord. Een economisch engagement, een sociaal project.

FOD Economie. (2016). Productiepark kerncentrales. Geraadpleegd op http://economie.fgov. $\mathrm{be} / \mathrm{nl} /$ consument/Energie/Nucleaire/kerncentrales/Productiepark_kerncentrales/\#. WYm5XHptBbM op 8 augustus 2017.

Graetz, G. (2014). Uranium mining and first peoples: the nuclear renaissance confronts historical legacies. Journal of Cleaner Production, 84, 339-347.

Jambon, J. (2016, 3 januari). Stillegging Doel 1 bewijst dat veiligheidssysteem werkt. Het journaal (M. Tanghe, interviewer). VRT.

Jenkins, H. (2004). Corporate social responsibility and the mining industry: conflicts and constructs. Corporate Social Responsibility and Environmental Management, 11(1), 23-34.

Kopytko, N. \& Perkins, J. (2011). Climate change, nuclear power, and the adaptation-mitigation dilemma. Energy Policy, 39(1), 318-333. 
Kramer, R.C., Michalowski, R.J. \& Kauzlarich, D. (2002). The origins and development of the concept and theory of state-corporate crime. Crime and Delinquency, 48(2), 263-282.

Larrain, J. (1983). Marxism and ideology. Atlantic Highlands: Humanities Press.

Le Soir. (2015, 1 december). Prolongation de Doel 1 et 2: voici les détails de l'accord.

Lenzen, M. (2008). Life cycle energy and greenhouse gas emissions of nuclear energy: a review. Energy Conversion and Management, 49(8), 2178-2199.

Levi, M. \& Horlick-Jones, T. (2013). Interpreting the Fukushima Daiichi nuclear incident: some questions for corporate criminology. Crime, Law and Social Change, 59(5), 487-500.

Lhotka, O., Kyselý, J. \& Farda, A. (2017). Climate change scenarios of heat waves in Central Europe and their uncertainties. Theoretical and Applied Climatology, 1-12.

Lynch, M.J. \& Stretesky, P.B. (2013). Green criminology. In: F.T. Cullen, \& P. Wilcox (eds.). The Oxford handbook of criminological theory. New York: Oxford University Press, 625-645.

Mabrouk, F.L. (2017, 8 december). N-VA zegt njet tegen Energiepact met kernuitstap. De Standaard. Geraadpleegd op www.standaard.be/cnt/dmf20171207_03231019.

Marghem, M.-C. (2016, 6 januari). Marghem: 'Onze kerncentrales zijn veilig'. Terzake (A. Beck, interviewer). VRT.

Martín, D.S. \& Mar Rubio-Varas, M. del (2017). Freshwater for cooling needs: a long-run approach to the nuclear water footprint in Spain. Ecological Economics, 140, 146-156.

Mousseau, T.A. \& Møller, A.P. (2014). Genetic and ecological studies of animals in Chernobyl and Fukushima. Journal of Heredity, 105(5), 704-709.

Nesterenko, A.B., Nesterenko, V.B. \& Yablokov, A.V. (2009). Chapter II: Consequences of the Chernobyl catastrophe for public health. Annals of the New York Academy of Sciences, 1181(1), 31-220.

NIRAS. (2017). Soorten radioactief afval. Geraadpleegd op www.niras.be/soorten-radioactief -afval op 28 juli 2017.

Nucleair Forum. (2016, 22 september). Kernenergie in de strijd tegen de klimaatverandering. Geraadpleegd op www.youtube.com/watch?v=TCTCIuH1OaE.

Nucleair Forum. (2017a, 3 augustus). News - Belgische energiemix juli 2017. Geraadpleegd op www.nucleairforum.be/actualiteit/nieuws/belgische-energiemix-juli-2017 op 10 augustus 2017.

Nucleair Forum. (2017b). Hoe zit dat met de $\mathrm{CO}_{2}$-uitstoot? Geraadpleegd op www. nucleairforum.be/thema/energie/hoe-werkt-een-kerncentrale.

Nucleair Forum. (2017c). Hoe zit het eigenlijk met ons kernafval? Geraadpleegd op www. nucleairforum.be/thema/kernafval/hoe-zit-het-eigenlijk-met-ons-kernafval op 8 augustus 2017.

Nugent, D. \& Sovacool, B. (2014). Assessing the lifecycle greenhouse gas emissions from solar PV and wind energy: a critical meta-survey. Energy Policy, 65, 229-244.

N-VA. (2017). Energie. Geraadpleegd op www.n-va.be/standpunten/energie.

Open Vld. (2016, 26 augustus). Open Vld energievisie: 'Tedereen maakt zelf schone energie.' Geraadpleegd op www.openvld.be/?type=nieuws\&id=1\&pageid=87914 op 11 augustus 2017.

Opsal, T. \& O'Connor Shelley, T. (2014). Energy crime, harm, and problematic state response in Colorado: a case of the fox guarding the hen house? Critical Criminology, 22(4), 561-577.

Poumadère, M., Bertoldo, R. \& Samadi, J. (2011). Public perceptions and governance of controversial technologies to tackle climat change: nuclear power, carbon capture and 
storage, wind, and geoengineering. Wiley Interdisciplinary Reviews: Climate Change, 5(2), 712-727.

Ramana, M.V. (2017). An enduring problem: radioactive waste from nuclear energy. Proceedings of the IEEE, 105(3), 415-418.

Ramana, M.V. \& Ahmad, A. (2016). Wishful thinking and real problems: small modular reactors, planning constraints, and nuclear power in Jordan. Energy Policy, 93, 236-245.

Ruggiero, V. \& South, N. (2013). Green criminology and crimes of the economy: theory, research and praxis. Critical Criminology, 21, 359-373.

Scheire, L. \& Van den Abeele, F. (2009). Wat als de olie op is? Het ultieme boek voor wie energie nodig heeft en ze niet kan missen, de harde feiten, de mythes doorprikt. Gent: Borgerhoff \& Lamberigts.

Socolow, R.H. \& Glaser, A. (2009). Balancing risks: nuclear energy \& climate change. Daedalus, 138(4), 31-44.

Soenens, D. (2017). Lobbyen in de Wetstraat. Berchem: EPO.

Sovacool, B.K. (2008). Valuing the greenhouse gas emissions from nuclear power: a critical survey. Energy Policy, 36, 2950-2963.

Van Horenbeek, J. \& De Boeck, A. (2017, 30 januari). N-VA houdt niet vast aan kernuitstap in 2025. De Morgen. Geraadpleegd op www.demorgen.be/binnenland/n-va-houdtniet-vast-aan-kernuitstap-in-2025-b5531988/.

Vander Beken, T., Dorn, N. \& Van Daele, S. (2010). Security risks in nuclear waste management: exceptionalism, opaquiness and vulerability. Journal of Environmental Management, 91(4), 940-948.

White, R. (2008). Depleted uranium, state crime and the politics of knowing. Theoretical Criminology, 12(1), 31-54. 